\title{
João Mendes de Almeida (*)
}

\author{
Rafael Corrêa da Silva Sobrinho
}

Nunca desproporção maior se assinalou entre a magnitude do assunto e a pequenez das forças do orador como na hora presente!

Sinto-me alquebrado ao peso da honra que me conferio o Instituto mandando fazer o elogio histórico de seu Presidente Honorário. Si me fosse possivel tirar partido da circunstancia, como o perigo da batalha que se vai ferir esforça os brios ao soldado valoroso, o ilustrado auditório teria do orador que lhe ocupa a atenção ao menos uma oração de mediana valia. Mas o não terá tal: não me encarregou o Instituto dos Advogados de uma simples narração biográfica, em que viessem assinalados os dias notaveis de sua carreira e com precisão inquiridas as datas dos acontecimentos; mas, determinando que fizesse o elogio histórico, quís o Instituto que eu trouxesise a esta assembléia, notavel pelos homens que se ocupam de letras, a historia deste país durante os dias do celebrado morto, e estudasse nela os mais notaveis acontecimentos que influiram no seu espirito e nas suas ações, bem como estudasse tambem, onde, quando e por que modo ele influio nos acontecimentos em que se achou involto e de que foi parte. E como em um homem grande como este, no qual as feições singulares de sua estatura bastariam para outros tantos discurisos, não se sabe o que mais requer a admiração - si o valor politico de seus talentos, si o valor jurídico de seu nome, si o jornalista, si o legislador, si o homem de letras, não pretendo anunciar ao selecto auditório que me ouve uma distribuição ciceroniana da materia; o quero apenas que vossa benevolencia não me leve mal o repetir neste exórdio palavras de um seiscentista do melhor quilate, tratando da vida de outro Joño. Direi em pouco, portanto, da vida e feitos de JoÂo Mendes de AlMEIDA, varão ainda maior que seu nome... e ajudaremos o pregấo universal de

(*) Conferencia feita, em 1898, por iniciativa do Instituto dos Advogados de São Paulo, e em comemoração do falecimento de João Mendes de Almeida, presidente honorario daquela entidade. 
sua gloria com este pequeno brado, porque dúrão as memorias menos nas tradições que nos escritos. (1)

\section{PRINCIPIAREI}

Quando se quebrou em 7 de Setembro de 22 o vinculo que nos prendia a Portugal e resultou a independencia do Brasil, fato devido mais á ação providencial da Natureza do que inespirado pela liberdade dos povos, as idéias dominantes aqui no Sul, onde a força contra a Metrópole se mostrou desde logo sinão mais energica que em outra parte, ao menos mais ruidosa e temerosa, eram de repelir o absolutismo em qualquer de suas manifestações. Ao passo que pelo Norte tanto maior quanto mais setentrional a Provincia se expandia certa resistencia, no Sul os homens da camarilha do Principe, a cuja vóz se deve o brado de rompimento, se atufavam reciprocamente de liberalismo. Isto fez facil o contágio da exageração nesses principios do indivíduo para a família ou do individuo para os agrupamentos, por maneira que anelava cada qual ostentar-se e ser havido como mais infenso que ninguem ao senhorio da metrópole e ás doutrinas do regimen absoluto.

No decurso de alguns anos se fez caudal a corrente. No Ric e São Paulo, onde o pensamento era uno, porque os mesmos homens davam ação á política lá e cá, tornou-se quasi impossivel o govêrno. $\mathbf{E}$, ou porque a aluvião posera fóra de navegabilidade o baixel imperial, ou porque entrara em seus planos acionar além do Atlantico outra política, passa na historia o 7 de Abril de 31 como explosão de exageraçōes liberais.

Esse resultado não aquietou a ninguem: o espírito conservador que não tinha ainda coadunado um grupo, mas que só existia numa atmosfera anônima, fez-se de luto; oo espírito liberal, como o incendio que quanto mais cresce e devora, mais quer crescer e devorar, tirou do 7 de Abril incremento para sua desapoderada carreira. Preponderando o Brasil Meridional no govêrno, pouca ponderação já deixa ver a beira do abismo em que estava o país, desequilibrada a balança governamental representativa: numa das conchas o pêso enorme e cada dia mais avolumado das idéias liberais; na outra uma pouca de sã doutrina, massa impalpavel a pedir á Providencia corporificação.

No regimen dos governos constitucionais-representativos si a nação não tiver duas forças tendentes ao recíproco embate, corporifi-

(1) Jacinto Frerre, "Vida de D. J. Castro", liv. I. princ. 
cadas em duas grandes porções de seus mais aptos habitantes, ou já não é nação, porque lhe falta a primeira condição da vida, ou desaparecerá no caos do peor despotismo, qual é o de uma multidão poderosa a calcar a massa impotente do país.

Já no tempo da Regencia trina, do seio do partido vitorioso surgiram homens que esforçaram travar a roda do liberalismo, passo que afoitavam não tanto para firmar ou aperfeiçoar o sistema constitucional, como principalmente para se amparar da morte certa e prevista.

A frente deles FeIJó, Ministro da Justiça, dizia: “Tudo; todavia agora tudo se deve e se pode fazer legalmente, nada porém pela violencia e pela desordem".

A tentativa era de todo imbele: tais homens copartícipes de todos os sucesso's que trouxeram a nação à borda do precipicio, não se podiam levantar com eficácia contra a torrente. Demais, a mais, no ímpeto de aparar a onda, talvez se arreceàssem dos ANDRADAS, de Carrós, e de outros, apontados como restauradores de PEDro I que tinham talvez por si a maioria do Senado.

A "Defensora da Independencia" foi uma associação que se fundou à inıstigação de Evaristo DA VEIGA, o qual escrevia no "Aurora": "Os bons patriotas devem trabalhar para que a revolução gloriosa de Abril se não perca nos abismos da dissolução social. 0 despotismo é sempre despotismo, quer exercido por um homem, quer nas mãos de muitos". Em contraposição, o partido exaltado levantou a associação denominada Federal.

Com a demissão do Ministério, o Senado entrou a condescender com a revolução. As duas casas do parlamento discutiram reformas pedidas em nome do 7 de Abril; do que resultou, graças ao Senado, aparecer mais iminente a necessidade dos principios Conservadores.

A timidez, porém, do Senado na senda dos bons princípios contrastava com a audácia do liberalismo sempre fervente. Na Regencia de Feisó, ao discutir a fala do trono e ao tratar da interpretação do Ato Adicional, foi que primeira vez se proclamou pelos lábios do Honorio Hermeto, Alves Branco, Araujo lima e outros a necessidade de pôr um paradeiro ás idéias de 31, que vinham de longa data assoberbando a nação. O natural foi que os princípios conservadores tomassem corpo entre os antigos restauradores. Os parciais do Regente tomaram o bando dos revolucionarios de Abril sob o pendão do partido liberal. 0 grande problema não estava ainda resolvido, mas a ebulição começava a ser poderósa.

A Provincia de São Paulo, na qual pelo que já vem dito, lavrava o incendio, tinha de mais a mais como um fóco de exageração aos princípios democráticos a Academia de Direito. Não é muito portanto 
que désse de si lógo e lógo a revolução de 42, que se soube alastrar por Minas e Rio Grande. o pretexto fôra a lei de reforma da Policia e Processo Criminal publicada em 41. São Paulo politicamente era o Padre Feisó com os homens e grupos largamente conhecidos pelos apelidos de Andrada, Vergueiro, Paula Souza ,Souza Queiróz, Souza Barros ,Tobias, Toledo, Pais de Barros. Mais tarde, vasta sucessão destes, destacando-se Rodriguez dos Santos, os Andradas moços e Carrão.

Abafados pelo numero e pelo prestígio das famílias e homens que esses apelidos relembram, os elementos conservadores apenas despontavam, e não conseguiam medrar. Houve homens eminentes do lado conservador aproveitados e postos em S. Paulo como lentes. Mas a escassez do pessoal determinava que fossem logo colocados nas cadeiras das Camaras, de modo que quasi nada deixavam de sua pessoal influência nesta Provincia.

Nem a repressão dos motins ocasionados pela revolução de $\mathbf{4 2}$ deixou nesta Provincia frutos e forças que pudessem contrastar grcissas coortes liberais.

Então, talvez para cimentar a pacificação das Provincias do Sul, os estadistas cogitaram da politica de concíliação. Não é facil dizer que erros ou que acertos frutificaram nesse terreno. E certo, porém. que os principios conservadores que alta e grandemente se impunham como necessidade de salvação pública, iam definhando com proveito só e exclusivo da revolução de Abril.

Satisfazer aos liberais e comedir-lhes os exageros pela governação das Provincias que lhes eram confiadas, eis o plano, maxime em S. Paulo, cujo teor de existencia já descrevemos qual era.

Começou de presisa a demonstrar sua nefasta influếncia a política de conciliação. Os liberais absorviam em si as forças conservadoras; dest'arte o Sul, continuando a ser o largo e tradicional teatro de suas facções, nunca teria partido conservador e batalhador. Foi então que apareceu na vivaz arena política o jovem Dr. Joño Mendes de Almeida, juiz ainda na cidade de Jundiai, e tendo apenas 25 para 26 anos de idade. Alistou-se entre os que não admitiarn outra posição política que não fosse uma adesão inabalavel a certo sistema de idéias e principios e que pensavam que a solução do problema social estava não na célebre politica de conciliação, mas só e unicamente no esforço em pról da formação do partido conservador. Essa posição de combate sem recuo e sem ousadias perigosas imporia ás forças naturais da nação a necessidade e a utilidade de se congregarem em dois bandos, regularisando dest'arte o funcionamento do sistema constitucional. 
Coube-lhe em sorte S. Paulo, arena trabalhada e avassalada pelo liberalismo, sinão o mais exaltado no terreno das lutas armadas, sem duvida o mais potente e válido pelos elementos naturais das pessoas e familias, pelos elementos da tradição sempre continente desde a Independencia e finalmente pelos elementos que já frutificavam no parlamento.

Dissemos qual o plano da politica de conciliação. Digamos quais seus meios de agir e qual o papel de JoÃo Mendes de Almeida neste passo da historia.

A formação do Ministério Conciliador do Marquês de OLINDA foi uma coroa triunfal para a política de conciliação. A esse ato respondeu JoÃo MENDES DE ALMEIDA com um protesto mal ouvido no momento, mas que seus tenazes esforços e o correr do tempo avolumaram.

Fundou a "Lei", periódico cujo primeiro numero traz a data de 7 de Setembro de 1857. Si a missão da "Lei" era a doutrina, o jovem batalhador se multiplicava em muitos para alistar eleitores, congregar grupos, excitar os chefes, porque tudo isto era organisação dos elementos partidários.

A Politica de Conciliação realisava sua missão fazendo cooperar simultaneamente liberais e conservadores no govêrno, na administração e na politica.

As eleições se faziam por lístas comuns: eram patentemente chapas de fusão. Foi o que inspirou logo no primeiro número da "Lei" um artigo em que se lê: "A fusão é um impossivel absoluto nos governos livres, e o empenho em conseguíl-lo, além de ser improficuo, desmoralisa o sistema que nos rege".

O sentimento politico, esse apanágio dos grandes patriotas que ele possuia em sumo gráo, condensara em seu coração uma dedicação sem limite aos principios e ás idéias. Eis porque exclamava:

"Si a conciliação importa a dissolução dos partidos;

Si a conciliação é o túmulo que se abre para enterrar as antigas idéias;

$\mathrm{Si}$ finalmente a conciliação importa o assassinato moral da honra de cada um e da conciencia de todos;

Foi certamente assa uma politica nova e que por sem duvida repelimos en quanto a fé em nossos dogmas e a conviç̧ão em nossos principios não se extinguir em nosso coração.

Repelimos a conciliação como sistema politico, porque isso importaria a aniquilação dos principios, a extinção da fé nos mais 
santos dogmas, e a canonisação do interesse privado como único élo capaz de ligar homens de idéias diversas".

Demais ele entendia que a conciliação, longe de cimentar a obra conservadora, que salvara o pais da voragem de 7 de Abril e de seus consequentes, tendia a destruí-la e a propelir de novo a nação em terreno resvaladio. Essa politica nefasta em vez de paz e concórdia, acenderia lutas perniciosas aos interesses da Patria e inglorias para os combatentes. Não ha incendio mais traidor e consumidor que o que se ateia nas faceis acendalhas dos interesses particulares e de ocasião: a fumarada que se expande perturba a visão da ordem superior. Dahi os ódios pessoais e a depressão do carater geral. $\mathrm{O}$ amor dos inimigos partidarios, sentimento cristão do maior alcance politico, só se cultiva na luta elevada e nobre das idéias e principios. Não passava tambem despercebida a Joño Mendes DE Almeida a impossibilidade moral de que ois liberais abrissem mão de seu programa e suas idéias, que tantos anos a porfia tentaram impôr á nação, e ás vezes pelo modo perigoso da mão armada.

Em honra aos magnatas dessa grei, d'onde sobressairam homens de tanto merecimento, nunca Joño Mendes de Almeida acreditou que a desistencia dos principios de 31 se traduziria em obra, não obstante acerrimas afirmações de alguns daqueles estadistas, que para mais logo colorir o pregado desaparecimento do partido conservador, asseveravam extinta a necessidade de levar por diante as reformas de 7 de Abril. Que se acabasse, diziam, que se fechasse o ciclo do partido conservador; basta que perdurem na historia o eco de suas glorias.

A uma folha liberal que escrevia: "O perigo das revoluções já não póde ameaçar o Imperio e o partido que a elas contrariava pode. deixar de existir", replicou valente " $\mathrm{Na}$ verdade, si a politica atual inutilisou os partidos ao menos aparentemente, o trono deve se lembrar que o futuro não tem garantia. 0 tigre finge dormir para melhor caçar sua vitima. 0 sono é breve; o despertar é terrivel! Sempre firmes nas nossas crenças, nunca jamais deslaçaremos a causa do trono da nossa; e, sì hoje nossos serviços não são exigidos, amanhã - não realise Deus a nossa profecia! iremos caminho da honra batalhar pela nossa bandeira".

Não the cabia no espirito a Joño MENDES DE ALMEIDA que houvesse homens de govêrno capazes de abandonar os principios. E dizia francamente: "Nós fazemos justiça a esse partido: o principio da reforma da Constituição foi inscrito e ainda o está em sua bandeira. Os chefes desise partido não serão tão falsarios para com aqueles, cujas paixões políticas, agitaram com essas idéias de reformas, 
abandonando-as por amor de interesses privados e elevadau aspira. ções! Não, nós não os supomos Janos políticos".

E segundo se deparava ocasião, a firmeza do homem inquebrantavel manifestava o ardor de sua tenacidade.

Quando em plena Assembléia Provincial, um dos mais autorisados Chefes - Paula Souza, declarou para maior consolidação da política conciliadora, que não eram mais liberais nem coisa alguma, rebentou de sua pena um artigo fulgurante sob o titulo: Os principios liberais sem preço e abandonados.

"Que pretendem, dizia ele, com esta repugnancia de seu passado, de suas crenças, de seus principios, de suas idéias, enfim de sua bandeira?

Não desejamos, e nem o faremos, comparar nossos adversarios politicos a 0 is soldados da Roma corrupta e dissoluta, que abandonavam seus penates por um pouco de oiro. Não podemos, entretanto, nos furtar á estupefação quando vemos lidadores outróra tão desenfreados de exageradas idéias sacrificarem ao momento, ás conveniencias de um só dia, essas mesmas idéias!

Conviriamos que nossos adversarios, com os pés em falso no poder, aparentassem alguma moderação no desenvolvimento de seus. antigos programas;

Conviriamos que, receando voltar á condição de vencidos, quizessem preparar a opinião pública para que a vitoria plena de seus contrarios lhes fosse menos pesada e prejudicial;

Conviriamos até, finalmente, que refletindo melhor sobre a prosperidade futura do país e sobre os meios únicos adequados de fazer atingir a ela, se arrependesse de suas exagerações nas lutas passadas, e quizessem com mais patriotismo, ainda que firmes na realisação de algumas de suas idéias mais moderadas, concorrer com os cont servadores para o melhoramento moral e material do Imperio;

Não convịmos, porém, que os liberais façam o triste papel que estão representando e que os seus chefes ou seus representantes digam aos amigos em plena Assembléia: - Estavamos enganados, pleiteavamos por vãos principios, e sacrificavamos inutilmente os nosisos esforços, a nossa comodidade, a nossa fortuna por falsos e anárquicos dogmas. - E por que um tal sistema? Dar-se-á acaso que julgarão os conservadores tão ineptos para acreditarem nessas estudadas palavras como sendo as da paz e concordia?"

Em sua dedicação aos principios ele não podia compreender que os adversarios fossem infieis á causa que até ali defenderam com tanta galhardia.

"Para o homem político como para o homem particular, dizia, a fidelidade é uma virtude, é conseguintemente um dever". 
Em seu atilado espirito a política de conciliação era tática do partido liberal. Respondendo á "Regeneração", jornal conciliador que se levantou na Côrte do Imperio, e que julgara necessario abrir polêmica com a "Lei", modesta folha de provincia, afirmava: "Sòmente os liberais utilisam no apoio a essa politica, porque é ela a ponte de oiro para o dominio exclusivo de suas idéias. Que o contemporaneo, fiel ainda que infeliz soldado do partido liberal, a abrace, a defenda, a popularise, nada mais justo, nada mais natural; mas os conservadores... esses não fariam senão suicidar-se lentamente".

E quando, como argumento perentório, a "Regeneração" lhe replicou que muitos conservadores e homens já notaveis, como Honorio Hermeto e Olinda, se haviam congregado á sombra do pendão conciliador, ele triplicava resoluto e com aquele vigor que só dá a consciencia intemerata: "Convença-se o contemporaneo que o povo já não se ilude com essas mistificações: o povo compreende por demais que esses ex-conservadores passaram-se para as fileiras opostas. Em política ha só dois caminhos: quem não é por nós é contra nós. Esses, pois, que se ligaram aos homens vitimadores do partido conservador, não podem mais ser considerados pertencentes a eisse grande partido".

Acabara de ser vencido o partido liberal. Fracassado o plano da maioridade, não tinha João MENDES DE Almeida razão de crêr que era apenas tática liberal que estava em ação e que o inimigo se lançaria por despeito do malogro, no mar tempestuoso das revoluções? Tudo induz a crêr que sim.

São Paulo era quem dominava na política do país. Entrava nos planos da conciliação entregar a administração e govêrno desta provincia aos liberais. O Ministério Olinda nomeou presidente de São Paulo o senador liberal Ferinandes Torres.

Não tardou muitos dias depois da posse que desenvolvesse um govêrno adito de todo ponto aos liberais. Nasceu a luta desde logo grande: os jornais da época dão atestados da reação contra os conservadores. Ao aplauso dos liberais, a "Lei" respondia em uma serie de artigos - Guerra aos conservadiores, nos quais discutia os atos e fatos da governação da provincia, realisados em detrimento e perseguição dos adversarios politicos.

Seu patriotismo rompia nestes bradas de energicas queixas: "Convem que não haja ilusão: em certas bocas as mais belas profissões de fé conciliatorias não passarão de mentiras e só servirão para a conquista facil, do fim almeịado e dantemão tramado. Esperemos entretanto, ainda o repetimos, para não sermos taxados de intolerantes, que se veja até onde chega a elasticidade da bôa fé liberal. Os pontífices pagãos riamıse de seus deuses no tabernáculo 
e invocavam ante o povo a majestade de Jupiter. 0 futuro nos dirá si da administração atual convirá dizer que consigo e seus amigas ri-se e zomba da Conciliação e que entretanto a proclama e deifica nas salas de palacio".

Demais, ao mesmo passo que os liberais declaravam dissolvido3 os dois partidos; afastado o perigo de revoluções e portanto sem mais razão de ser a existência do partido conservador, concomitantemente levantava de tempo em tempo, e com estudada cautela, idéias de reformas ofensivas á Constituição, colorindo seus passos com alegar ao público que se devia aproveitar a calmaria para o estudo de algumas questões que como reformas de caracter geral fossem levadas a efeito de acôrdo. Evidente se ostentava o adormentar nos conservadores a viveza de seus principios para que os deixassem no esquecimento. Uma folha liberal levantou nosses termos a idéia de algumas reformas, alegando que, si em verdade feriam a Constituição a época era propicia para uma revisão, atento o estudo de treguas e não se olhando os partidos com vistas suspeitosas. A "Lei" respondeu: "Como se engana o contemporaneol Por mais calmos que pareçam estar os tempos, cumpre não olvidar que muitas vezes o vulcão arde sob a neve, a cinza muitas vezes oculta o fogo. Presentemente a conciliação é a neve, a conciliação é a cinza. Ainda quando a época fosse sinceramente calma, acreditais que seria tempo de rever a Constituição e de galvanisar os espíritos com idéias novas? Si a época fosse tal, seria então conveniente que melhor empregassemos todos os nossos esforços para a execução fiel daquela nossisa magna Lei e não para suscitar inovações que podem desvairar os espíritos. A política então não deveria viver de agitações, e as inovações apenas podem dar esse resultado". E acrescentava: "Demais, desde que a Constituição houver de ser modificada ou alterada, nosssa adesão não póde, não deve ser invocada em apoio de idéias de reforma. Quereis por ventura que desconheçamos um dos nossos principios cardiais - o de defender de qualquer investida de reforma a Constituição e que façamos em tiras nossa bandeira?" Longa foi a campanha; e JoÃo MENDES DE ALMEIDA, como para falar de mais alto e ser mais bem ouvido, apezar de haver já debate travado entre a "Lei" e os órgãos conciliadores da Côrte, resolveu escrever no "Jornal do Comercio" consecutivos artigos de combate, que fizeram época.

Infelizmente desses artigos, de que dá ampla notícia a fama com que são celebrados, não pudemos colher á mão um só, porque o tempo que nos deu o Instituto foi pequeno para tão largas indagações. A luta de JoÃo MENdes de Almeida tinha em largo campo a teoria e a prática. Ao passo que doutrinava, metia em movimento os eleitores para que se arregimentassem, punha-se accessivel a todos 
para lhes cuidar dos negocios de toda isorte, interessava-os nas questões sociais e ficou em breves anos o centro de todo movimento politico na Provincia. Trabalho ingente! Tanto maior quanto era gandissima, como já vimos, a massa do partido liberal, prosperado na provincia por sem numero de circunstancias. JoÃo MENDES DE Almeida resolveu vencer e sobrepujar todas as dificuldades. Não houve tropeços que não afrontasse e dos quais não se visse logo a cavaleiro. A atividade que desdobrou em toda sorte de trabalhos chegou a ser pasmosa. Os correligionarios que a ele se aproximavam uma vez não mais tornavam a solicitar serviços aos eminentes liberais desta Capital, como era o costume. E, muito ao contrario, fez-se até alguma mutação de oposta corrente, tal era a presteza indistinta na prestação dos serviços pessoais. Dele podemos dizer com inteira verdảde o que disseram da atividade e labor de Julro Cesar: Monstro de atividade, horror de diligencia. Nada lhe parecia estar feito enquanto restava que fazer (2).

Começou o partido conservador a manifestar o produto de seuss labores não só em colegios do interior, como aqui na Capital, nomeadamente no coração da Cidade - a Freguezia da Sé, - onde em alguns anos tinha o partido conservador um de seus baluartes inexpugnaveis.

Com muita perspicacia entendeu João Mendes de Almeida interessar os correligionarios no progresso material da Provincia. Este lado do público serviço andava descurado: os liberais, preocupados nas grandes reformas, desviavam a atenção de certa ordem de fenômenos postos em evidencia em proveito e engradecimento do partido coniervador.

Começou de escrever, e levou em serie, longos artigos, em que versava os melhoramentos de que precisava não só a Provincia, como tambem a Capital.

Uns ele mesmo lembrava e promovia; outros inspirava a correligionarios que ocupavam lugares de administração ou na Asusembléia provincial, de modo que, ao mesmo tempo que se prestavam serviços de geral utilidade, a gratidão dos eleitores não podia ser indiferente ao partido conservador.

Os melhoramentos municipais desta Capital, desque apareceu na vida pública, não tiveram maior paladino.

As novas ruas para facilitar comunicações e estimular a construção predial, o inicio dos calçamentos das ruas, a feitura do mercado, do

(2) Crc. etc. etc. 
teatro e cemiterio, a iluminação pública, o que tudo em 1857 estava muito abaixo do prestigio e fóros da Provincia e da Capital, são melhoramentos que devem a ele o mais vigoroso impulso. E não the passou despercebido um assunto, fonte de importantes vantagens para a riqueza pública e particular e para o desenvolvimento geral, dos estados: as estradas.

O segredo do grande progresso de São Paulo, disse um estadista brasileiro, está principalmente no empenho que pôs em suas estradas, rasgando os sertões, abreviando as distancias, dando lugar à facil exportação e importação e tornando menos ásperas as viagens e portanto mais habitaveis os centros sertanejos.

Os artigos cheios de calor com que a "Lei" tratava desse assunto vêem-se na coleção dessa folha. E logo inspirou aos conservadores que tinham assento na Assembléia Provincial a apresentação de um projeto, creando um credito ilimitado para tal serviço, declarando-o imprescindivel e urgente.

Quando apareceu o projeto na Assembléia, apareceu a "Lei" explicando o passo dos correligionarios, e entre mais coisas, dizia: "Convém mais do que nunca auxiliar a administração em tal conjuntura. Não queremos com isso dizer que nos tenhamos conciliados com a administração no que respeita à política. 0 infortunio geral nos obriga a tréguas, não porém a adesão. $A$ conciliação ainda é para nós um simples palavrão e um indecifravel hieroglifo, que em relação aos melhoramentos materiais não tem o encanto e não póde operar os milagres da lira de Orfeu. O partido conservador tem resolvido prestar todo apôio e adesão à administração no que respeita a estradas, em atenção ao estado calamitoso em que elas se acham; mas não pode fazer côro com ela na entoação de idilios à harmonia de coisas opostas". Espírito superiormente complexo, não podia João MENDES dE Almeida esquecer que não são os melhoramentos materiais que elevam um povo e que a missão do seu partido naquela emergencia devia ser mais completa e real. E assim se exprimia, incitando a administração, de que era adversário, a praticar melhoramentos de toda ordem: "Não estamos dispostos a trilhar a senda da antiga escola, cujo principal dogma era a negativa de pão e agua aos seus adversarios. A lei é a expressão do justo, e nós conservadores, que propugnamos tão sublime principio, não negaremos ao Presidente o que lhe fôr devido. Não são, porém, os melhoramentos materiais as unicas necessidades de um povo, e a obrigação exclusiva de um govêrno justo e ilustrado. A Historia nos apresenta uma longa série de povos, cujos dias foram marcados por uma prodigiosa sucessão de monumentos. Mas não foram por isso os mais felizes e hoje esses suposto padrões de gloria apenas nos 
atestam, pelos signais de fumo e sangue que apresentam, os estragos do punhal e do facho das discordias civis. Melhoramentos morais, e como primeira condição o cumprimento da lei e a sincera satisfação do justo e do honesto, tal é o primeiro dever de um govêrno e o unico monumento que, não temendo o fumo e o sangue, lhe pode dar imarcescivel glória".

Eis porque, pairando sempre numa região altaneira, entre os atos de progresso moral queria a atenção dos governos para a distribuição da justiça. Mostrando os embaraços da organisação forense, apontava os remedios que facilitariam à's partes a solução de suas pendencias.

Um mal da época era o fato, devido a causas várias, de serem os cargos de juizes nas localidades ocupados por individuos de larga parentela. Contra isso clamou alta e frutuosamente.

"Um juiz, dizia, que exerce seu cargo em lugar sujeito à alternada preponderancia de familias, e que pertence a uma destas, não pode jamais satisfazer com sã consciencia as exigencias do público serviço. Sua reputação corre perigo de ser atassalhada, porque, embora justo nas decisõés, tem contra si a circunstancia de pertencer a uma familia da localidade, e, em tal caso, não é dificil supor que seus atos são modelados por inspirações domesticas".

Não foi um de seus menores brados patrioticos o que reclamou contra uma doutrina, então em voga, de que os presidentes de Provincias podiam suspender os magistrados. E, como medida de apressar a administração da justiça, reclamava desde então por um tribunal de Relação nesta e outras Provincias do Imperio.

Apezar de pugnar com a maior tenacidade que quanto à ação e quanto ao programa os partidos se mantivessem em suas extremas, reclamava que para os cargos públicos se nomeassem homens de mérito isentos de qualquer parcialidade.

A colonisação, o ensino público e o ensino profissional foram objeto de seus solícitos escritos.

Nem paravam na imprensa seús esforços: os "Anais da Assembléia Provincial" testemunham que projetos como deputado ou presidente daquela corporação tiveram a inspiração de suas luzes ou se realisaram com o suor de sua fronte.

A guerra sem cansaço, e quotidianamente sustentada contra a política de conciliação, tomou corpo pelo engrossar das fileiras adversarias, mas não podia negar em breve tempo frutuosos resultados. 
Via-se a vitoria dos que entendiam que a politica nacional exigia a permanencia dos dois partidos com suas balisas inamoviveis, com seus programas bem definidos, para que bem funcionasse o sistema constitucional.

A abertura das Camaras em 1858 foi a ocasião mais bem deparada para o ataque decisivo contra o Gabinete Conciliador. Em resposta à fala do trono, EusEbio dE QueInóz no Senado desfechou golpes de morte na política do gabinete e em seguida o Visconde de Uruguay. Morta a política de conciliação, triunfava a politica dos principios e das idéias, a politica em que "a fidelidade aos principios políticos professados era uma garantia de ordem e estabilidade para as instituições".

o valor desse serviço nacional é inestimavel. Basta ponderar que, traçadas de uma vez as lindes dos dois campos, o partido liberal assumio sua verdadeira feição constitucional não só contido pela resistencia conservadora, como principalmente moderado pelo patriotismo indiscutivel de seus homens principais, que bem compreenderam que as idéias exageradas de 31 não se compadeciam com a felìcidade da Patria.

Daí a moderação das lutas incruentas dos dois partidos, moderação que nos soube dar longo ciclo de paz interna, exemplo de amor da Patria, que frutificou dias de glória e progresso, dias de grandeza nacional, justo orgulho de todos nós, qualquer que seja a parcialidade politica em cujo seio haja militado.

Estava portanto resolvido o magno problema, fato primordial para nossa completa vitalidade de nação livre. Para este resultado, talvez ninguem foi mais esforçado que JoÃo MENDES DE ALMEIDA.

Tanto mais admiravel em toda carreira trabalhosa que perlustrou brilhantemente, quanto é certo que, homem de pouca idade, é fóra do natural e do corrente que haja apanbado em toda sua amplitude problema de tamanha complexidade.

Não se pense que como bracileiro, orgulhando-me desse passado, eu desconheça que nossos partidos politicos infelizmente nem sempre se mantiveram em suas órbitas de ação.

Muito razoavelmente o partido liberal acusava o conservador de romper os diques que deviam conter suas manifestações de ordem politica, adiantando-se a reformas que aos proprios liberais parecia 
conveniente adiar. E por sem dúvida essa foi uma das causas que, tomando nos últimos tempos vastas proporções e impelindo o país vertiginosamente pelo caminho das reformas, o precipitaram no abismo da revolução.

Não queremos aqui indagar as origens desse êrro ou suas causas, nem apurar responsabilidades, das quais mui poucos estão isentos; mas é nosso intento apenas patentear que, assim como ninguem trabalhou mais que JoÃo MENDES DE ALMEIDA para estabelecer o regular funcionamento do regimen constitucional representativo no Imperio, tambem ninguem mais do que ele se esforçou para a perpetuação dessa obra, mantendo bem discriminados os principios e a ação dos partidos, já doutrinando incessantemente, já dando o exemplo de inabalavel "firmeza de idéias, segurança de principios e fidelidade partidaria.

Esse exemplo ele dava principalmente quando era chamado no Parlamento a estudar alguma questão politica. Examinarei alguma para pôr em relêvo quão seguros eram seus passos sempre coerentes com os principios da escola conservadora.

\section{ATO ADICIONAL}

Em 1870 cogitou a situação conservadora de fixar, por interpretração legislativa, o verdadeiro sentido de algumas disposições do Ato Adicional á Constituição Politica do Imperio. Os conservadores tinham o pensamento de promulgal-a a fim de realisar a grande idéia contida no artigo 71 da Constituição - a descentralisação administrativa das Provincias, visto que as opiniōes, diferentes, quanto á estensão e compreensão dessa idéia, ocasionavam deduções desencontradas. Já não era suficiente a lei interpretativa de 12 de Maio de 1840.

Entretanto havia o perigo de, sob o pretexto de interpretação, sacrificar-se o principio constitucional da centralisação politica, o que não era dificil acontecer pela pouca atenção de uns e pela fraqueza de outros que, acostumados ainda aos antigos processos da politica da conciliação, não duvidariam ceder no programa do partido.

João MeNdes de Almeida que foi aliás o membro mais operoso da comissão, não quiz ocultar suas desconfianças e disse que não era crente do Ato Adicional, moderado embora pela lei de 12 de Maio de 1840; mas que, sendo aquele Ato já uma instituição constitucional, a lei que o interpretasse deveria limitar-se a regularisar sua influencia no jôgo do sistema, tanto quanto apenas fosse indispensavel para 
conjurar o afrouxamento da unidade política do Imperio. Compartilhava da opinião dos que desejavam uma mais larga descentralisação administrativa contanto, porém, que mais se fortificasse a centralisação política; e era essa a razão por que aplaudia outras disposições do projeto.

Segundo o seu modo de ver, a descentralisação politica é uma fraqueza por ser o isolamento; e nem se deve separar do corpo carecedor de direção a cabeça que o deve dirigir.

Si a centralisação politica, dizia ele, é a vida nacional, porque é a consolidação, porque é a solidariedade, porque é, enfim, a confraternisação pelo sentimento elevado e nobre de uma patria comum, a centralisação administrativa produz efeitos justamente contrarios, e até debilita e anula aquela pelas susceptibilidades que o descontentamento sói excitar entre Provincias mais favorecidas e Provincias que o são menos.

Relativamente á instituição municipal, no intuito de ascegurar o Municipio contra a Provincia, entendia ele que as assembléias provinciais tinham sobre as camaras municipais ação muito restrita; e que só o poder legislativo geral tinha o direito de regular, e sobre um tipo de absoluta uniformidade, a instituição municipal, como era expresso no artigo 169 da Constituição. As assembléias provinciais, pensava ainda, competia apenas exercitar as atribuições que o Ato Adicional lhes conferira, mantendo-se dentro da esfera traçada pela lei organica das camaras municipais.

E, nesse firme pensamento, denunciando sempre que o Ato Adicional matara as liberdades municipais em proveito da centralisação provincial, indicando os perigos de tais condescendencias, alterou com o melhor exito, diversas disposições do projeto que então se discutia.

Diante desse parecer de 19 de Setembro de 1870, o govêrno resolveu retirar o projeto. E assim aparou JoÃo MENDEs DE ALMEida um golpe já vibrado, talvez de bôa fé, contra os principios conservadores.

\section{REFORMA JUDICIARIA}

Em 1845 agitou-se a idéia da revisão da Lei de 3 de Dezembro de 1841, menos para levar a efeito qualquer reforma do que para aquietar o espirito revolucionario. A experiencia, dizia a propria comissão, não tem sido bastante para perfeitamente orientar o legislador sobre os defeitos da Lei de 3 de Dezembro; mas manifestava, contudo, a tendencia de tirar aos funcionarios policiais quaisquer atribuições judiciarias, de garantir a vitaliciedade e a inamovibili- 
dade da magistratura, de extender o habeas corpus, acentuando-se assim o inicio do movimento para a reforma judiciaria, que se revelava em propostas e projetos apresentados quasi anualmente.

De 1869 em diante acentuou-se ainda mais esse movimento pela restrição da prisão preventiva e pelo alargamento das fianças. 0 ministro da justiça de então, José dE Alencar, tinha apresentado um projeto sobre a reforma policial; e, sujeito esse projeto a uma comissão, esta, analisando a necessidade indeclinavel de separar as funções policiais das jüdiciarias como garantia da bôa administração da justiça e da liberdade individual, apresentou um substitutivo.

Mas no seio da propria comissão surgiram divergencias: alguns negavam que qualquer vantagem pudesse provir para a justiça da incomunicabilidade dos réus, ao passo que evidentemente muito sofreria com isso o direito da defeza. Recusavam tambem qualquer competencia policial aọ juizes de paz.

O Dr. João Mendes, declarando que aliás não fazia parte dessa comissão veiu em auxilio dos que assim pensavem, e ponderava que as declarações do indiciado ou réu deveriam ser feitas sempre perante a autoridade judiciaria, a não ser que jamais se considerassem como confissão e, sim, como simples auto de informações, sujeito a ulteriores provas, as declarações que fossem feitas perante a policia visto que a presunção é esta: Nemo contra se dicit, nisi aliquo cogente.

Opondo-se á transformação dos termos de segurança e de bem viver, sob o titulo de caução dos suspeitos, escreveu entre aspas, á margem do seu exemplar de coletaneas de prọetos, o seguinte pensamento de Schiller: "Tudo póde ser sacrificado aos interesses do Estado, menos os direitos do individuo e da humanidade".

Mas, só em 1871 foi possivel dar um golpe na lei de 3 de Dezembro de 1841 e seu Regulamento.

PromuIgou-se a lei n. 2033 de 20 de Setembro de 1871; e o govêrno viu desde logo que ninguem melhor do que o Dr. João MENDES DE Almeida poderia dar regulamento a essa lei : e aí está o decreto n. 4.824 de 22 de Novembro de 1871 , que bem revela como agiu ele nesta questão importante.

\section{ELEMENTO SERVIL}

O problema da escravidão, problema dificilimo por suas ligações com os varios fenômenos de ordem politica e principalmente de ordem social, problema com que a sorte duramente oprimia nossa nacionalidade e que desprestigiava o nosso papel de povo livre e 
diminuia nossa estatura perante a culta humanidade, desafiou desde os nossos primeiros dias de nação independente as cogitações dos mais altos patriotas.

Nessa pleiade em que resplendem no céu da História patria o Bispo Azeredo Coitinho, o Marquez de Queluz, José Bonifacio, cognominado o Patriarca, Eusebio de Queiroz, Rio Branco, Dantas, João Alfredo, e João MENdes de Almeida uma estrela de singuiar fulguração.

E notavel posição e notavel merecimento!

O ilustre brasileiro teve ainda nesta magna questão não sómente a missão do homem de estado com todas as responsabilidades que que essa espinhosa posição impõe, mas tambem a missão do propagandista. Não excitar paixões, mas despertar os sentimentos de justiça e caridade, eis os estímulos suficientes para inspirar grandes ações aos povos de nossa raça.

No exame retrospectivo de sua ação nesta grande causa, depara-se logo a campanha que ele abrio na imprensa em 1859 contra a tendencia do proprio govêrno em iludir o Decreto de 25 de Dezembro de 1853, fazendo depender as cartas de emancipação aos africanos livres da audiencia previa daqueles que houvessem arrematado seus serviços. Era patentemente um artificio para criarlhes uma escravidão de fato.

$\mathrm{E}$, quando era poderoso o elemento escravagista e ainda muito alto falava a voz dos interesses contra a sagrada causa da libertação, nesta Provincia principalmente, ele arriscando suas aspirações politicas, sempre inferiores à nobre causa das idéias, rompeu a campanha em pról do fiel cumprimento daquela lei, que já era uma conquista no caminho da grande causa da libertação dos escravos. Tal era a força dos elementos escravagistas que avisos governamentais eram expedidos eludindo a medida legislativa, fazendo depender de tal informação a emancipação legal. " $E$ ' irrisoria, exclamava ele, a doutrina do Govêrno; e tanto mais irrisoria quanto, a prevalecer tal doutrina, muito breve já não será possivel a emancipação dos africanos". "E quando se pretendeu aplicar essa doutrina do govêrno aos africanos que prestavam serviços em estabelecimentos públicos, nem com essa limitação ele se conformou: "Cremos que o legislador não quereria que os africanos ficassem permanentemente escravos (pois importa o mesmo), só porque prestam serviços em estabelecimentos públicos. A sorte dos africanos, cujos serviços foram arrematados por particulares, não deve ser melhor do que a daqueles, que desgraçadamente ficaram logo sujeitos a prestar serviços em estabelecimentos públicos. A justiça protesta contra isso; e, quando não a justiça, ao menos a equidade". 
Ele queria uma propaganda esclarecida e não apaixonada; e por isso combatia a idéia de se fazer da magna questão uma questão de partido.

Quando em 1869 publicou uma série de artigos de subido valor, confrontando os programas dos dois partidos constitucionais à luz desta maxima, eminentemente filosófica - Pela verdade chegareis à liberdade, dizia: "A questão servil não pode ser uma questão de partido. E uma questão social que todos no Brasil desejam ver resolvida sem o prejuizo dos direitos individuais e sem a perturbação da ordem pública com o auxilio exclusivo dos principios morais e das máximas econômicas. É uma agitação prenhe de consequencias funestas a emancipação servil arvorada como bandeira de partido! E concurrentemente aconselhava o esfôrço comum para a resolução do triste problema, mediante medidas de prevenção em beneficio econômico do país, em vantagens da lavoura e em bem dos escravos e libertos.

"São certamente sedutores os principios, dizia ele, que aconselham a emancipação servil; mas é indispensavel certa prudencia na realisação da medida, afim de que o sofrimento não seja geral. Antes de tudo vulgarisa-se a necessidade de suprir o trabalho escravo pelo trabalho livre, de sorte que a população não veja na aspiração emancipadora um desastre e um retrocesso: a idéia frutificará sem menor esfôrço e, em tempo proximo, a substituição terá sido operada com todas as vantagens econômicas e politicas sem abalo algum".

Em 1870, quando já estava no poder o partido conservador, ele, como representante desta Provincia na Camara dos Deputados, animava a ação do govêrno e ao mesmo tempo doutrinava e dirigia na "Opinião Conservadora" palavras cheias de patriotismo e de verdade ao país: "A emancipação agora não é mais e sómente mera aspiração de individuos ou de associações particulares. $O$ mundo politico já estuda, explora e procura solver esse dificil problema de nossa sociedade, segundo os respectivos programas partidarios. A crise vai-se formando com maior velocidade do que se previa; não ha mais tempo de cogitar da transformação lenta do trabalho; a velha sociedade pôs agua por todos os lados e a salvação possivel consistirá no estudo e aplicação de meios adequados a diminuir ou atenuar os desastres dessa verdadeira revolução. A emancipação será brevemente um fato; é indispensavel portanto que nos preparemos para aceitá-lo, afim de evitarmos as graves consequencias de uma falaz crença na permanencia mais ou menos prolongada da instituição condenada. Por nossa parte não podemos deixar de clamar aos interessados: "Os acontecimentos condensam-se perigosamente; cuidai nos vossos interesses agricolas, afim de que a cur- 
preza não vos arruine; sêde providentes cogitando desde já na substituição do braço escravo pelo braço livre: a revolução que vem de cima e que consegue enraizar-se nas profundezas da sociedade é sempre eficaz; e os interessados, por mais poderosos que pareçam ser, são evidentemente impotentes para embaraçar-lhe o curso fatal".

E para bem se compreender como trazia enlaçados o papel de propagandista e sua missão politica, continuava: "A missão do Partido Conservador é, portanto, agora conjurar apenas maiores males, promulgando medidas legislativas que suavisem os rigores da crise e que preparem a harmonia entre o trabalho livre e o capital. 0 partido conservador no govêrno não pode assegurar aos lavradores sinão uma transição cautelosa, mantendo o crédito da propriedade rural durante a transformação mais ou menos rápida do trabalho. Nada de ilusões; a imprevidencia será em breve um êrro irremediavel, quando for proferida a última e esperada palavra sobre a questão".

E assim, em subsequentes artigos, ia levando de manso a propaganda tenaz e complexa, ao mesmo tempo que sua autoridade, então influente nos negocios do partido, auxiliava o govêrno a dirigir prudentemente e guiar sem atropêlo o movimento, e, quanto ao corpo legislativo, inspirava-o a promulgar medidas que suavisassem os rigores da crise. Correu entretanto o ano de 1870 sem que nada de positivo fizesse o govêrno; até que ruindo o gabinete presidido pelo Marquês de S. VICENTE, subio ao poder o célebre Ministério 7 de Março de 1871, presidido pelo Visconde do Rio Branco. o que então se deu não se apagará da memória dos contemporaneos; e de futuro ninguem deixará de rememorar as glorias dessa campanha parlamentar, que honra sobremodo o patriotismo brasileiro.

Ninguem mais denodadamente auxiliou o notabilissimo Visconde na sua tarefa altamente civilisadora e politica, que se concretisou na lei gloriosa de 7 de Setembro de 1871, chamada do ventre livre.

Além de sua ação no parlamento, é notabilissima sua ação na imprensa. Durante todo o Jongo curso dos debates parlamentares na Camara dor Deputados e no Senado, escrevia diariamente no "Jornal do Comércio" artigos de combate, elucidando as questões, esclarecendo a opinião pública. Não preciso de encarecer o alto merecimento do "Guarda Constitucional". Seus artigos foram inseridos como notas esclarecedoras dos debates na obra que o visconde do Ro Branco em nome do Govêrno Imperial mandou publicar para eterna lembrança dessa inolvidavel campanha parlamentar. 
João Mendes de Almeida foi proclamado então pela opinião do país como o mais prestimoso colaborador do Visconde do Rio Branco naquela grande obra social e política. "Levando dia a dia na imprensa da Côrte o mais valioso concurso à discussão parlamentar, empenhada com tamanha veemencia, disse o "País" em 1887, ninguem mais dedicado e valoroco que o "Guarda Constitucional" que tão galhardamente bateu-se ao lado do glorioso promotor da lei". 0 biógrafo que nos perpetuou em um livro a vida e feitos daquele titular, chefe do gabinete 7 de Março, exaltando com a maior admiração esse grande serviço patriótico do ínclito Visconde, ergueu logo ao pé dele a figura do nosso celebrado morto, a quem comparou naquela conjuntura com "o lavrador que dirige vigorosamente a charrua entre as camadas de um sólo rebelde."

Outra apologia inexcedivel de seus serviços é a que se contem na frase do Conselheiro Dantas, quando foi vencido na luta parlamentar para a libertação dos sexagenarios, frase que nos foi revelada pelo representante da Diocese na oração funebre proferida nas solenes exéquias: - "Faltou-me um João MENDES. Eu não tive como Rio Branco o "Guarda Constitucional!"

No vigor ainda da idade e em plena ação politica, Joño Menjes DE ALMEIDA teve azada ocasião de intervir no movimento para a solução final do problema servil. Pela lei de 71 estava cortada a fonte da escravidão; mas a escravidão existia e oferecia seu acabamento um complexo de dificuldades tormentosas. Em 1882 publicou a "Provincia de S. Paulo" um projeto de sua lavra, explicado em longa série de artigos, cuja idéia capital era a abolição imediata da escravidão, transformada em servidão mediante medidas de alto engenho e valor pratico para a nação e para a lavoura.

Eis aí, senhores, como agio na magna questão servil este operoso brasileiro. Ninguem revelou mais do que ele prudente dedicação e elevada competencia na extinção da escravidão, esse mal inveterado, do qual dizia o Visconde de CAyrú que era tão grande no país que não cabia no engenho humano o extirpállo sem gravissimos inconvenientes.

Uma outra questão de nossa historia politica em que o proceder do eminente morto foi pautado pela mais correta dedicação aos principios, sustentada patriotica e nobremente, foi a famosa Questão Religiosa. 
Sejam quais forem as opiniões que se agitem no terreno politico, sejam quais forem as crenças individuais, a ninguem é dado contestar que, fixado na Constituição do Império o fundamental principio da união da Igreja com o Estado, não era lícito a qualquer dos partidos constitucionais concorrer para a perturbação das relações entre os dois poderes.

Sinão a justiça, ao menos a prudencia e os altos interesses da Patria assinavam ao Govêrno Imperial uma posição mais cordata, si bem que o procedimento do representante que aqui tinha a Santa Sé atenue na Historia, em bem do Govêrno, o peso da culpa, ficando dividida a responsabilidade entre o poder civil e a diplomacia da Curia Romana.

Longe de nós apreciar aqui o procedimento do Internúncio Apostólico naquela triste quadra, sacrificando os direitos sagrados da Igreja defendidos galhardamente por dois Apóstolos ardentes da fé e da verdade. Tanto quanto convém aos interesses da justiça na historia, a responsabilidade de cada um perante os homens e perante Deus está apurada na obra sobre a "Missão Penedo", trabalho do" denodado Bispo D. Antonio de Macedo Costa, morto arcebispo da Baía.

Ao homem de principios e crenças o famoso Gesta tua non laudantur nem podia entibiar a fé, nem devia perturbar a consciencia.

Ao homem politico, zeloso de suas responsabilidades perante a Patria, só o amor à verdade, à justiça, ao direito é que lhe devia dominar os atos. Por isso foi que se achou ao lado dos que maior denodo mostraram na defeza dos direitos da Igreja, fossem quais fossem os acordos e acomodações dos diplomatas.

"Não admitimos, escrevia ele, o sacrificio de nossas convicções e crenças religiosas a certas conveniencias governativas, que perturbando a harmonia do Estado com a Igreja, são por isso mesmo a negação dos verdadeiros principios conservadores. Si o procedimento dos que assim agiram foi conforme à verdade, à justiça e aos interesses do país, que o diga a marcha posterior do proprio Govêrno Imperial, recuando da trilha que havia seguido e acatando a paternal encíclica de Pio IX de 29 de Abril de 1876, que aprovava os atos dos dois Bispos de Olinda e Pará. Diga-o tambem o sentimento nacional, que na monarquia e na república tem sempre revelado o mais acendrado amor à Fé Católica e ao romano Pontífice."

Esta questão politica levou-o a fazer-oposição ao Gabinete 7 de Março, a quem tantos serviços havia prestado. Qual o seu papel parlamentar nessa quadra, disse-o o "Globo Ilustrado" referindo-se à energia da oposição em frente dos elementos governistas, dirigidos pelo Ministro J. Alfredo, de quem foi até à morte grande 
amigo: "O Senhor JoÃo Mendes de Almeida, um espirito capaz de tecer uma rêde de conspirações, rodeava o Ministro com mil ardis de guerra".

Os contemporaneos ainda têm viva memoria dos prodigios de habilidade e de tática que ele então praticou. As questões de gabinete sucediam-se, assim transformadas por eles as mais insignificantes questões de ordem ou regimentais. E ainda agora muitos jornais do Rio, noticiando seu falecimento, fizeram referencia a essa sua celebre campanha de oposição parlamentar ao gabinete 7 de Março.

\section{REFORMA ELEITORAL}

Felizmente nem sempre faltou espirito público em nossa Patria; e houve uma época em que causava má impressão o resultado eleitoral de câmaras unânimes ou quase unanimes da parcialidade polilitica dominante. Todos reclamavam a reforma da lei $n .^{\circ} 387$ de 19 de Agoslo de 1846. O Imperador, por seu lado, notava a cada passo a necessidade da representação das oposições para verdade no sistema representativo.

Veio a lei $\mathrm{n} .^{\circ} 842$ de 19 de Setembro de 1855, denominada lei dos círculos; mas verificou-se que esta lei faltara aos seus fins, porque, si alguns opocionistas foram eleitos, não se devia atribuir o resultado ao influxo da nova lei; sim ao preconcebido plano de facilitar-se-lhes o mandato: acrescendo que baixara o nivel intelectual, da representação nacional porque, tendo as influencias locais se substituido aos diretorios dos partidos, os homens notaveis e habilitados foram sacrificados a aspirações de parentes e protegidos de tais influencias.

Para remediar esse mal, veio a lei n.o 1082 de 18 de Agosto de 1860, que creou distritos de três deputados.

JoÃo MENDES DE ALMEIDA era enérgico em apontar as razões por que estas leis de 1855 e de 1860 seriam impotentes, como foram, para remediar o mal. 0 problema não precisava sair do Pacto Fundamental para obter satisfatoria solução: a eleição, segundo a Constituição fazia-se por Provincias. "A Provincia é a circunscrição constitucional, dizia ele; basta assegurar por cautelas bem ordenaras a representação das minorias, porque, representadas estas, todas as opiniões e interesses se encontrariam e se reconheceriam no parlamento: e, assim, representadas as minorias, seriam ipso facto representadas as oposições".

Em 1873, tratando-se de eleger comissão para dar parecer sobre projeto do govêrno, e que se converteu em lei, o deputado JoÃo 
MEndes, atenta a sua grande competencia, foi quasi unanimemente sufragado por seus colegas, quer da maioria quer da oposição. E esca competencia mais una vez se revelou de modo brilhante no parecer de 4 de Agosto de 1873, verdadeira monografia sobre os diversos sistemas da representação das minorias, e no projeto substitutivo que então apresentou.

Esse parecer e esse substitutivo mereceram os elogios de Aurry Viter em sua obra "La vraie réforme électorale" e os aplausos da da Associação Reformista de Genebra no seu Relatório anual sob o titulo "Les progrès de la réforme électorale en 1873". Uma revista de estudos de legislação e de estatística comparadas publicada em Paris, em 1888, referindo-se a esse parecer, assim se exprime: "Considéré, non seulement dans son ensemble comme dans ses détails, le rapport de la commission spéciale est une oeuvre en tous points remarquable, vraiment considérable; elle denote, comme le fait remarquer M. Naville, une connaissance trés étendue de tous les travaux rélatifs à la question; la commission ne pouvait réfondre d'une manière plus éclatante à la confiance que la Chambre lui avait temoignée." E, referindo-se ao projeto substitutivo, diz: "Ce projet substitutif, du rapporteur de la commission, M. Mendes DE Almeida est si important que nous aurions désiré en transcrire ici toutes les dispositions; mais après M. Naville, qui l'a exposé en detail, en le comparant avec le projet primitif et les principes de la théorie, ce serait vraiment une témérité de notre part de vouloir le faire de nouveau; qu'il nous soit donc permis à ce sujet de renvoyer simplement aux écrits précients de cet éminent philosophe et publiciste".

Compreende-se quão honroso era para o parlamento brasileiro que pareceres e projetos apresentados por um de seus membros merecessem o estudo e os elogios de filósofos e publicistas de diversos paizes do velho mundo.

Em defesa desse parecer e desse projeto proferiu Joño Mendes de Almeida dois discursos, nas sessões de 27 de Julho e de 13 de Agosto de 1874, e dos quais vários trechos vêm transcritos na revista referida: do último desses discursos disse em pleno Parlamento o provecto estadista liberal Martinho Campos que era um dos mais importantes que ele ouvira na Camara e que só com proferi-lo João Mendes de Almerda fizera jus à gratidão da Patria.

Após o seu discurso na sessão de 27 de Julho, o Govếrno reconheceu que, para o voto incompleto produzir o almejado resultado de garantir a representação das oposições, era necessario adotar algumas das idéias por ele emitidas e especialmente abrir mão das circunscrições distritais preferindo as provinciais: e assim, em nome do govêrno, o Visconde do Ruo Branco o declarou na Camara - no Senado em sessões de 11 de Maio e de 10 de Agosto de 1875. 
Dest'arte concorreu ele com o ilustre Visconde e com o llustre estadista JoÃo AlFrEDo para que o eminente filósofo e publicista, o citado M. Naville emitisse a respeito do Brasíl o seguinte elevado conceito: "Le Brésil était le premier des grands États qui, pour l'ensemble de ses élections represéntatives, ait brisé le joug des majorités électorales. C'est un honneur pour cet Empire".

Quando a situação liberal, inaugurada a 5 de Janeiro de 1878, ergueu o grito da reforma da Constituição para a eleição direta censitaria, JoÃo MEndes de Almeida não pôde conter um protesto, que se traduzio em um panfleto de combate - "O Senado e a Reforma Eleitoral". Esse panfleto é um primor de estilo e de doutrina; e os maiores vultos do partido conservador no Senado, na longa discussão que ali sofreu a reforma, fizeram-lhe os mais subidos encômios.

Promulgada afinal a lei, o Ministro do Imperio, de então, não duvidou consultar seguidamente a superior competencia de JoÂo MENDES DE Almeida para regulamentá-la.

$E$ eis ai como na questão eleitoral, sempre de magna importancia para um povo livre, agiu e operou o ilustre brasileiro.

Na imprensa exclamava convicto: "Os partidos arregimentados são um sumo bem para o país; preferimos as bandeiras que flutuam às bandeiras que se dobram e se ocultam. Dois partidos constitucionais bem definidos são as válvulas dessa máquina moderna, denominada sistema parlamentar".

Toda sua ação doutrinadora, após o definitivo estabelecimento dos dois partidos na política nacional, foi à luz da máxima que firmou logo ao iniciar sua carreira política: "Para o homem político, como para o homem particular, a fidelidade é uma virtude e conseguinternente um dever".

Ainda nos últimos tempos do Império, quando na verdade os partidos se confundiram, precipitando-se os dois nas reformas revolucionarias, ele à custa de suas mais legítimas ambições, defendia os princípios, combatia com ardor pela doutrína e pelas ações essa quasi geral infidelidade, cousa apontada por toda nação como determinante de um movimento revolucionario, como meio de transformação politica.

$O$ esfôrço doutrinario que ostentou é uma obra ingente, que se fixou nos jornais e nos panfletos: bastando notar a "Sentinela", 1879; "Manifesto ao Partido Conservador de São Paulo" em 1882; e a "Sentinela da Monarquia", nos últimos mezes do Império. Então, sua posição politica, si até aí tinha sido resoluta contra a confusão dos principios, atingio as proporções de um sacrificio heróico, que 
consumia no bem público todas as forças do espirito, todas as vitais energias do preclaro morto.

Dava-se então a corruptio optimi pessima. Não era já o partido liberal (tremenda lição da historia!) que se contaminara de cxcessos democraticos. Era o proprio partido conservador que não tivera força para conter um seu ministerio, o qual perdendo o amor ao fundamental princípio da união da Igreja com o Estado, não cuidara de encaminhar com moderação e prudencia as relações dos dois poderes - temporal e espiritual. Era o partido conservador que já se preparava por elementos prestigiosos para cooperar com os liberais ou levar a efeito por si a revolucionaria reforma do sistema eleitoral indireto, pretenção democratica exagerada que já vinha de 31 .

Esse abandono dos principios já produzia em São Paulo, uma vida politica mesclada dos republicanos e conservadores, tomando proporções prejudicialissimas, baseadas na estreiteza de vínculos de sangue entre membros eminentes de uma e outra parcialidade.

Era tão monstruosa a ligação, que tocava as raias da inépcia! João Mendes de Almeida, si preferisse a satisfação de ambiçóes e sucessos individuais, teria feito causa comum com tal monstrugsidade; mas, guiado sempre por um ideal superior, os principios de sua escola, deu-se pressa em mostrar sua ação veemente contra tamanha anomalia e desfraldou imediatamente a legendaria bandeira, que hasteou bem alto. Sabia pela lição da historia, pelo estudo dos fatos coetaneos e pela dedução das leis morais que São Paulo conti nuava como a grande foria do liberalismo revolucionario, que já agora se ia avolumando com o ataque resoluto a integridade nacional.

Foi quando fundou a "Sentinela" para defender aquela bandeira, que talvez nunca tivesse por si tanto vigor e valentia como agora, sendo entretanto a mesma que defendera com a "Lei" e com a "Opinião Conservadöra".

O programa de seu jornal naquela dificil conjuntura da vida nacional ele bem o definio em poucos termos: - "A Sentinela" é francamente conservadora; advoga principios, não paixões, segue idéias, não homens; prefere sempre a lei divina à lei humana. Em outros termos a "Sentinela" quer uma politica verdadeiramente cristã".

Dessa época em diante João Mendes de Almeida, grande de espiríto e de conciencia, como diz Dupont White dos homens que baseados nas probabilidades aventam o futuro, labutou como um apóstolo contra essas tendencias democraticas do partido conservador, mentindo ao seu velho programa quer quanto às idéias, quer quanto aos fatos, pois que em São Paulo a vida do partido conser- 
vador era de tal afinidade com o partido republicano, que houve caso de unidos sustentarem chapa comum!

"Queremos bem definida a politica", dizia ele, referindo-se à primeira eleição geral pela do terço, quando já se propalava sem rebuço que o govêrno conservador incluia na chapa oficial o chefe do partido republicano, cujo eleitorado adotara em transação essa mesma chapa. "O caminho das transações em politica é sempre a estrada larga para a quebra da disciplina e para o enfraquecimento das crenças", não cessava de bradar.

Entretanto a carreira era vertiginosa! Circunstancias várias concorriam para mais precipitá-la, nenhuma acudia a contê-la.

A aliança dos dois partidos nesta Provincia deu em vérdade aos republicanos, como eles bem ó diziam, "a ocasião de exercerem no proprio coração das forças consideradas aliadas, uma ação dissolvente, mais funesta à monarquia do que todas as propagandas ostensivac e todas as lutas nos comicios".

Si ele revelava-se ou não o "homem grande de espirito e conciencia" que os publicistas consideram uma necessidade primordial no govêrno das nações, que o digam os fatos posteriores. Ainda nos meses derradeiros do Imperio ele deu o alarma na "Sentinela da Monarquia".

Mais segura previsão dos acontecimentos era impossivel! E tanto mais admiravel quanto é certo que o levante de 15 de Novembro passa como surpreza. Surpreza! Sim, porque sua vóz não foi ouvida. $O$ melhor é repetirmos as palavras sábias publicadas naqueles dias: "Estão em conflito os dois principios antagônicos: a monarquia e a revolução. Acreditar que a revolução se deixará convencer ou seduzir será ilusão, que custará caro aos que a tiverem. Por ora a revolução astucia, mostra-se indecisa, ostenta certo respeito ao velho Imperador. Mas este estado de indecisão não pode ser mantido no meio de agitação que os desertores da causa monarquica vão fomentando. A revolução caminha, e a guerra civil aparecerá. Ou bem monarquista ou bem republicana. Não ha meio termo que não seja ilusão ou má fé".

Não havia falar mais claro. Todavia para insistir nos perigos da Pátria e evidenciar a situação, a "Sentinela" de 10 de Novembro (quatro dias antes do levante!!) estampava: "Nunca a revolução esteve tão perto dos degráos do trono!"

Si é verdade que as revoluções devem ser inculpadas aos que as tornam inevitaveis e não aos que as fazem, segundo um escritor 
moderno, é fóra de duvida que dentre os politicos do Imperio este avulta na historia puro de culpas perante a conciencia nacional.

Nem a nação lhe negará como politico que sua figura é das que têm maiores proporções, quando é certo que os hrecúleos forcejos pela causa publica, pela causa politica, pela patria enfim, eram elevadas manifestações da conciencia do dever, por entre as mais asperas hostilidades pessoais, que sua propria estatura inteletual e moral provocava no meio e nas circunstancias em que se achou.

Uma das feições mais notaveis e brilhantes do espirito de JoÃo Mendes de Almeida foi o talento de jornalista. Assim considerado, não sei quem neste país excedeu ao nosso presidente honorario.

Sua arma predileta na politica foi o jornal. Considerava a imprensa "uma formidavel potencia social" e "o reflexo do espirito que bem ou mal domina a sociedade". E quando um jornal liberal lhe replicava, em um assomo de iniusto pessimismo, que a imprensa entre nós era inutil, porque não influia nem na sociedade nem no poder, redarguia que si ela queria "ver e seguir a verdade, falasse imediatamente com a autoridade eficaz da justiça, esquecendo a autoridade vã das paixões ou a autoridade falaz do interesse. Como quereis, exclamava ele, que a sociedade preste ouvidos à imprensa, si esta desvaira-se pela tentação de uma falsa grandeza ou pelas orgulhosas pretenções da razão pagã?" E quando ao seu insistente reclamo pela ação da imprensa, como capaz de grandes beneficios em uma época dificil de nossa politica, se lhe opunha a frase desalentadora - a imprensa é impotente! - redarguia: "Quem não compreende que nestas palavras ha um grito de valoroso esfôrço para apressar a resurreição do Direito? Deixemos nascer o sol; e não perguntemos quem nos ha de revolver a pedra da boca do sepulcro".

Mais do que por palavras, ele manifestou em obras a grande confiança na imprensa como uma força social de formidavel grandeza, manejando essa arma nas grandes pugnas que travou em nosso mundo politico e social.

No Brasil ninguem fundou e redigio tantos jornais. Toda vez que se levantou um problema politico ou uma questão social, podia-se esperar como certo o aparecimento de um perídico sob sua direção. Para a grande campanha do definitivo estabelecimento dos dois partidos essenciais no nosso regimen parlamentar, fundou a "Lei", como já vimos.

Para defesa dos principios conservadores, quando os dois partidos, em frente um do outro, disputaram algum tempo por ideias, fundou a "Opinião Conservadora". 
Para a defesa dos direitos da Igreja na Questão Religiosa fundou a "Sentinela", cujo programa, segundo já vimos, era a política subordinada aos principios cristãos, conforme a disposição fundamental do artigo 5. ${ }^{\circ}$ da Constituição do Imperio.

Para a defesa da monarquia na luta com a republica, vencedora a 15 de Novembro com a revolta militar, fundou o "Boletim do Partido Conservador" e "A Sentinela da Monarquia".

Assidua colaboração teve no "Jornal do Comercio", no "Diário do Rio de Janeiro", no "Apostolo" e na "Nação", órgão governista fundado no tempo do Ministerio 7 de Março.

No jornalismo puramente politico travou lutas ingentes cúm Otaviano, Saldanha Marinho e aquela coorte, notavel, que redigia a "Reforma", órgão liberal no Rio de Janeiro. José dE AlENGAR, contemporaneo, ora seu companheiro, ora seu adversario na imprensa, exprimia a grande admiração que por ele tínha nesta frase, que é uma verdadeira sagração: "No jornalismo não conheço tático e estrategista de mais recursos na polêmica".

$\mathrm{Na}$ época da questão religiasa adquirio o conceito elevado, que se traduz pelo cognome que mereceu de Veuillot Brasileiro, aclamado por amigos e adversarios.

Como Veuillot, tinha a ousadia do crente, manifestada nas obras e nas palavras, quer faladas, quer escritas, toda vez que fosse preciso dar testemunho do Evangelho e do amor à Igreja.

A obra jornalistica de João Mendes de Almeida é imensa e de merito permanente, porque encarava e discutia as questões com tal elevação, com tão alto espirito filosófico, que as novas circunstancias do tempo não the alteram a valia.

Como Girardin publicou "Souvenirs d'un journaliste" e "Questions de mon temps", e como Veuillot publicou "Paris pendant les deux sièges", JoÃo Mendes DE Almeida podia ter condensado em fartos e valiosos volumes as produções jornalisticas. No estado em que nos achamos agora, essas produções são talvez a unica obra no Brasil que pode formar, como disse Littré da de Armand Carrel, uma longa página da nossa historia. Por elas se podem conhecer as tendencias, os esforços, as lutas, os impulsos, as paixões de nossos partidos e de seus melhores paladinos.

Em verdade saber os tempos em que escreveu e os acontecimentos em que se achou parte, é poder afirmar desde logo que seus escritos são uma longa época da historia brasileira, escrita, discutida, minudenciada dia por dia, como a de Armand Carrel. E si é justa a critica de LITTRÉ, que prevenia os leitores do exclusivismo de opinião que dominava nos escritos do publicista francês, seria desnecessaria qualquer prevenção quanto ao jornalista brasileiro, que pairando na 
região dos principios e pugnando por eles, está isento e inculpavel de opinião.

\section{HOMEM DE LETRAS}

Com quanto JoÃo Mendes de Almeida se salientasse notavelmente como político, como jornalista e como jurisconsulto, não deixou de cultivar as letras sob outros varios aspectos.

Poucos homens públicos no nosso país escreveriam tão corretamente a lingua vernácula, e, sem duvida o conhecimento que ele tinha dos clássicos e das riquezas da lingua, muito contribuiram para realçar-lhe os méritos de jornalista e de advogado. 0 seu estilo de escritor tem qualidades de simplicidade e beleza, que o tornam de ótimo quilate. Conhece-se pela leitura que os seus escritos são espontaneos, sem o menor esforço; e isso explica por que produziu tanto, no jornalismo, na advocacia, nas letras. A facilidade com que produzia trabalhos escritos de maior valor que fossem sem desviar a atenção dos encargos de sua profissão e sem afastar-se da comunicação das pessôas que o procuravam era assunto de admiraço para todos; e, se não fora tal dom, teria conseguido desempenhar o seu papel de "Guarda Constitucional", na gloriosa campanha parlamentar da emancipaço servil, quando terminava quasi sempre à noite as sessões do corpo legislativo.

A nossa historia Patria foi assunto de suas locubrações, certamente impelido nisso por sentimento apurado de patriotismo. O valor desses seus estudos é estimado em muito; e a sua competencia nos assuntos da nossa historia o elevou a um gráo de autoridade magistral. O modo por que ele a estudou e a conheceu não é esse modo vulgar por que muitos a estudam e a conhecem: basta assinalar que, para aprofundar o seu estudo, ele tornou-se conhecedor autorisudo, à custa de paciente e admiravel tenacidade, da lingua tupibrasileira.

Melhor do que eu poderia fazê-lo, um notavel escritor brasileiro, - Dr. Joaquim Serra, deixou-nos uma apreciação do seu mérito de historiador. Referindo-se à sua obra "Algumas notas genealógicas" disse Joaquim Serra: "O Dr. João MENdes dE AlmEIda é um escritor de alto merecimento." Conquanto modestissimo no seu plano, as "Notas genealógicas" não são simplesmente como as tablinas dơs romanos, ou os "ricordi di famiglia" publicados em Florença, memórias e necrológios dos antepassados: ha nelas grande subsidio para a Historia e paginas que são admiraveis pela critica iluminada e pela erudição copiosa. 
Nesse numero devemos contemplar todos os capitulos do livro concernentes à descoberta de Cabral, ao sistema governativo colonial, às origens dos indigenas do Brasil, precedido de substanciosa sintese sobre a especie humana. As notas etnográficas, filológicas e historicas revelam o mais aprofundado estudo das nossas cousas, grande conhecimentos das velhas memorias e crônicas nacionais, lidas atravéz das luzes que tem derramado a ciencia moderna. Na parte puramente genealógica, ha muito pormenor interessante, muita pesquiza de valor real e que demonstra a verdade do dito de Camilo Castelo Branco sobre as vantagens que póde advir à história dos povos desses alfarrabios só referentes a algumas familias".

Além dessa obra, que mereceu tambem lisongeira apreciação de homens da estatura de Camilo Castelo Branco e Pinheiro Chagas, o sr. JoÃo MeNdes de Almeida publicou várias memorias interessantissimas para a nossa historia nacional. Mencionaremos as seguintes: "A Capitania de S. Vicente - São Paulo"; "Memoria sobre o nome America"; "Memoria sobre os nomes Amazonas, Solimões, Maranhão, Goíana, com referencia ao rio Amazonas", e "Memoria sobre qual o chefe principal da Nação Goianá, na região nomeada Piratininga".

Deixa uma obra inédita, trabalho monumental de paciencia e de saber: é o "Dicionário geográfico e etimológico da Provincia de São Paulo", em oito volumes. Essa obra já foi apreciada em uma grande reunião das pessoas letradas desta Capital em 1890 ou 91, merecendo admiração de todos e da imprensa.

Não sendo homem de fortuna, não logrou o prazer de conseguir dá-la à publicidade. Praza a Deus que algum dia possam as letras patrias ser enriquecidas com a publicação dessa obra de mérito.

Nos últimos tempos de sua vida, manifestava constantemente o pezar de não poder levar a efeito o seu projeto de dedicar ao Maranhão, sua Provincia natal, um trabalho igual a esse que dedicou a São Paulo, onde nasceram a sua esposa e seus filhos e que amava com todas as véras de sua alma.

Para despertar o amor às letras, chegou a fundar em 1887 a Sociedade dos Homens de Letras, neste Estado, do qual foi eleito presidente. 0 "País", encarecendo esse ato, assim se exprimiu: "S. Ex. demonstra que o seu espírito superior não se deixa levar unicamente pelas preocupações da politica".

\section{JURISCONSULTO}

Outra feição brilhantissima, tão notavel que quasi eleva ao pasmo, é a que mais o eleva no conceito do Instituto: é a de homem do 
Direito. Neste carater Joño Mendes De ALmeida consubstanciou em uma dificil e mui rara unidade as três principais manifestações do direito na ordem social: o jurisconsulto, o legislador, o advogado.

Como jurisconsulto, era um mestre cuja nomeada não teve barreira de Provincias no Brasil inteiro. Seus pareceres profundos no saber, copiosos na erudição, eram solicitados de longe e acatados como doutrina. Ao mesmo tempo grande cultor da historia universal e da lingua latina, comprazia-se de estudar nos originais as fontes e os comentarios do nosso direito. Daí a segurança, com que afirmava a adatação ou inaplicabilidade de certas regras e principios, segundo a necessidade dos tempos, a intenção do legislador, e os fatos ou relações que se queriam reguladas.

Nunca compreendeu desirmanados as papeis de jurisconsulto e filósofo e nunca admitiu divorcio entre o direito e a moral. De modo que aonde não chegava o texto para regular a hipótese, alcançava a dedução de seu espirito avezado a filosofar. E onde a rudeza do texto se contrapunha à bravura dos costumes, intervinha a moral como fundamento preexistente das humanas convenções.

Como legislador, afóra os conhecidos feitos parlamentares que já perlustramos em rápida resenha, onde o politico nunca se concebeu deslaçado do jurista, são muito de notar dois padrões da legislação brasileira, que são auréolas de seu grandioso vulto: o Decreto de 22 de Novembro de 1871 e o de 13 de Novembro de 1872.

Não se faz mister avivar em nossa memoria que o primeiro é o Regulamento da Reforma Jurídica, passo do nosso progresso reclamado de longa data como necessario por ambos os partidos, assunto em que já se haviam empenhado homens eminentes desde $1862 \mathrm{sem}$ distinção politica. S. Vicente, Sinimbú, Nabuco, Alencar, Muritiba, Sayão Lobato e outros. Levado a termo pelo Ministerio 7 de Março, - Govêrno Imperial escolheu para regulamentar essa momentosa Jei o nosso biografado. Excuso encarecer à vossa ilustrada proficiencia o mérito desse Regulamento que mais do que eu conheceis.

o outro é o Regulamento da lei chamada do Ventre Livre.

Quem poderia em verdade melhor regulamentar essa lei aurea do que o inclito guarda-constitucional? Relator, na parte jurídica, do parecer da comissão parlamentar que estudou o projeto do govêrno, aliava JoÃo MENDES DE Almeida a essa circunstancia a de ter sido o mais insigne campeão dos que fizeram vanguarda ao Visconde do Rio Branco na defeza do projeto. Conhecia mais do que ninguem as disposições, o alcance, o fim da lei; ninguem com mais perfeição era capaz de traduzir no Regulamento as intençōes do legislador, substanciadas na lei. 
o Visconde do Rio Branco, que dedicava todo seu sentimento patriótico a essa grande obra social e politica, bem compreendia que os mesmos sentimentos transbordavam no peito do jurisconsulto, que um dia na mesma pagina da Historia teria seu nome enlaçado ao dele e na gratidão nacional as mesmas bênçãos.

Como advogado mais avulta e se revela a grandeza do homem.

Ao serviço de um saber juridico vasto e profundo, tinha Joño MENDES DE ALMEIDA sobre outros colegas, igualmente provectos que ele, a vantagem de possuir um conjunto de peculiarissimas faculdades. Uma atividade que sabia cindir-se ao sabor dos negocios em manifestações variadas; um atilamento em delinear no espírito, lógo à primeira visão, toda a estrura intima dos casos, que mais parecia adivinhar que saber; uma tática inimitavel no ataque e na defeza, fina e sem ruido, antecipando de longe os planos do inimigo, de sorte que quando os golpes the vinham, já vinham imbeles, e muitas vezes eram retorquidos com vantagem e, quando os dava, levava o campo estudado para não sofrer surprezas, tudo isto dominado por uma consciencia religiosa do dever conferia áquele homem singular indisputavel bastão de marechal nas pugnas forenses.

Para ele a advocacia era um sacerdocio não só teorica, mas praticamente.

A identificação entre o patrono e o cliente era perfeitissima, realisando o preceito dos antigos:- Defensioni clientes incumbat tanto fortius quanto adversus potentiorem partem, et proprio quantumvis periculo. Identifique-se ao cliente tanto mais fortemente, quanto mais poderosa fôr a parte adversa, não obstante os perigos da própria vida (Duprn, De officio advocati, pag. 311).

Nunca porém se deixou nessas lutas forenses, que as travou formidaveis e renhidas, nunca se deixou cegar pela paixão, nem consentiu se transmudassem nos conflitos baixos do ódio e das inimizades pessoais as nobres contendas do saber.

Esta nossa profissão de advogado traz consigo um mal de sua propria compleição: é a condição perigosa e delicada de facilmente produzir situações acres. Só um esforço constante, ajudado pelas mais nobres qualidades de carater, é que consegue derivar os malus sucessos desses inevitaveis recontros.

Cada um de nós póde dar testemunho de quão dificil é este transe da nossa carrẹira, o qual desafia constante e põe à prova nossas civicas virtudes.

Pois bem. Quem ha aí, advogado jovem ou provecto, que, entranhado nas lutas do fôro, guarde para com ele, a par da admiração que ele captava e impunha, siquer um leve ressentimento? 
Eis aí, indubitavelmente, um de seus maiores elogios. ,Foi Joño Mendes de Almeida natural de Caxias, no Maranhão, onde nasceu em 22 de Maio de 1831, filho legítimo de Franando Mendes de Almejpa, capitão de milicias, português, e D. Esmerua Alves de SouzA. Tendo cursado a Faculdade de Olinda, teve o gráo de bacharel em Direito pela Faculdade de São Paulo ern fins do ano de 1853. Daí a um ano foi nomeado juiz municipal da Franca, lugar que permutou pelo de Jundiaí. Como juiz municipal de Jundiaí, teve ensejos de assumir a jurisdição de juiz de direito desta Capital, de cuja comarca Jundiaí era têrmo. Em Fevereiro de 1858 largou a magistratura e se fez advogado nesta Capital até a morte. Aqui casou em 1855 com D. Ana Rita Fontes Leite Lobo, de quem teve numerosa progênie.

Aqui foi jornalista; aqui foi vereador; aqui foi deputado provincial e presidente da Assembléia; por esta Provincia foi largos anos seguidos deputado geral; entrou duas vezes em lista senatorial. Sempre publicista, - sempre político, sempre declarado católico, sempre advogado. $O$ advento de $\mathbf{1 5}$ de Novembro, si perimio um dos campos de sua atividade - a politica, tornou mais intenso a cultivo das letras juridicas e o cultivo das letras sagradas e das obras de religião.

Fez-se grande em seu país, quem nunca perlustrou nem com intuito de recrear o espirito nem com intuito cientifico. 'Muito menos saio do Brasil.

A Sociedade de Geografia de Lisbôa o fez seu socio correspandente, titulo de honra que muito prezava, pois que sempre muito prezou o Reino de Portugal. Era sócio honorario do Instituto Histórico e Geográfico do Rio de Janeiro e do Instituto da Ordem dos Advogados Brasileiros.

Foi João Mendes de Almerda de elevada estatura, corpulento, porte ereto, olhar fito, barba inteira pouco basta e sempre curta e desđe muitos anos encanecida. Na conversação fluente, muito franco no dizer, às vezes mordaz, muitas vezes jovial. Na tribuna parlamentar, única que exercitou, não tinha o entono oratório; mas seus discursos eram fluentes, perfeitamente deduzidos, pareciam mais uma conversa pausada, sem lanços imaginosos. Pai de familia extremoso, a educação dos filhos foi sempre o melhor de sua atenção.

A vida the pareceu quebrada a meio desque ha quatro anos mais ou menos finou-se nesta cidade sua esposa. De então para cá, aquele élo que se partira na cadeia de seus dias, fortificara o coração a receber sem pavor o sinal da última viagem. 
Por outro lado, espirito altamente cristão, não se deixou pender para a extremidade oposta - amar e desejar a morte! Summum nec metuas diem, nec optes (3).

O que sentimos em nós parece que sentirá todo o auditório: perguntar porque fundo mistério, na ordem natural dos sucessos, a um homem que dispendeu frutuosamente os 40 anos de sua melhor existencia pelo Município, pela Provincia, pela Patria, pela liberdade dos principios, pela afirmação do carater, por tudo que foi grande e nobre, não se deu uma recompensa de nenhuma especie?

A resposta já vem dada ha muitos anos!

Cada nação, do mesmo modo que cada individuo, diz DE Marstre (4) recebeu da Providência uma missão que deve cumprir. JoÁo MENDES dE ALMEIDA, no discorrer dos sessenta e tantos anos de sua vida, não olhou uma só vez para traz sinão talvez para dizer consigo, no seio de sua alma humilde, que pouco havia feito, e muito era por fazer. Queixas da Patria ninguem lhe ouviu!

Jacintho Freire, do pouco que fez à patria pelo $4 .^{\circ}$ vice-rei da India, assim exclama:. "Si a pátria imitara a gratidão do império romano com filhos beneméritos, dera a lêr ao mundo as obras de $D$. João e Castro em sublimes estatuas, que, como anais de bronze, fossem volumes públicos a todas as idades". (5)

E VIEjRa, o mestre mais alto da oratoria e da lingua, dizia ao proposito: "Se vossos feytos forão romanos, consolai-vos com Catão que não teve Estatuas no Capitólio. Vinhão os estrangeiros a Roma, vião as Estatuas daqueles varõens famosos e perguntavam pela de Catão. Esta pergunta era a mayor Estatua de todas. Aos outros poz-lhes Estatua o Senado; a Catão o mundo. Deixai perguntar ao mundo e admirar-se de vos não ver premiado. Eśsa pergunta e essa admiração he o mayor e o melhor de todos os premios".

Que melhor estatua que a vassalagem que se lhe prestou no derradeiro dia? Desde o mendigo até o magnata, desde o proletario até o capitalista, desde o homem descalço até o magistrado superior, desde o operario até o lente, desde o negro até o sacerdote, abalou-se uma população à noticia de sua morte e disputou-se a alça de sua tumba como um derradeiro pagamento de gratidão, como uma reliquia de saudades!

(3) Montaigne, Essais, Cap. XXXVII.

(4) Considérations sur la Fr., Cap. II.

(5) J. Freire, V. de D. J. de Castro, Liv. 3.27. 
Falaram as vozes da imprensa bracileira em peso, falaram as corporações mais respeitaveis, falaram as assembléias politicas, falaram os homens mais eminentes do pais, falaram os sinos tos campanarios, os coros dos sacerdotes, as orações das virgens, e ninguem falou que não fosse para exalçar seu nome, suas virtudes, a perda da Patria, a dor do Brasil inteiro. Si as perguntas curiosas dos cultos excursionistas eram em Roma a estatua de Catão, o que vimos fazer por JoÃo Mendes DE AlmeIdA, e ainda o sentimos vivamente, porque não ha sessenta dias passados, isso tudo não póde ser sinão o pedestal de sua glória!

O Instituto dos Advogados se enche de prazer por contar em seu seio quatro filhos do celebrado morto, dos quais o homônimo de seu pai é nosso vice-presidente e um dos claros ornamentos no magistério superior; o segundo um dos notaveis advogados deste foro.

Os outros, ainda mui jovens, são esperanças certas das letras juridicas. Todos, vinculados tão fortemente pelo sangue, como pelo sentimento cristão que os inspira na mesma senda que seu venerando pai trilhara sem descanço, todos continuarão em simultaneo trabalho o que só ele bastara a realisar.

Esperte-os o exemplo paterno na cultura da jurisprudencia, afim de espertarmo-nos tambem a seguir com viveza e fervor os caminhos de seu profundo saber, como o outro Grego, que confessara de si lhe faziam perder o sono as proezas que lia do venturoso Milciades. (6)

o Instituto dos Advogados se preza da honra que deu a esta sessão o comparecimento das Exmas Filhas e mais parentes do ilustre morto, cuja vida relembramos hoje. Não é uma corporação cientifica como a nóssa que terá novidades para dizer ao coração desfibrado pela dor! Assaz consolaçōes já hauriram nas fontes inestancaveis da fé os descendentes Mendes de Almeida aqui presentes. Mas é força que lhes digamos em nome do Instituto uma palavra ao menos e será um pensamento conhecido de Valerio Maximo: - Que os cultos Romanos costumavam pendurar........

(Aqui o original está truncado)

(6) Fr. L. pe SouzA, H. de S. Dom. vol. 1,2. 


\section{NOTAS}

\section{ASSEMBLÉA PROVINCIAL}

Para o biênio de 1870-1872, o dr. Joño. Mendes foi eleito deputido provincial, da qual foi o presidente no ano de 1870. Presidindo a Assembléia, jamais foi suspeitada a sua imparcialidade no cumprimento das disposiçôes regimentais. Chefe da maioria do partido conservador, que então apoiava o govêrno provincial, a sua orienlação revelava-se nos artigos da "Opinião Conservadora", que então acompanhava, com verdadeira critica, os atos da Assembléia. Condenava o sistema de colonisação à custa dos cofres públicos, porque, dizia ele, "os recursos da Provincia são insuficientes para satisfazer proficuamente a todas as exigencias impondo ou facilitando ao govêrno preferencias que tanto corrómpem as nossas administrações", e apontando para as tristes experiencias desde 1841.

Foi ele quem, em 3 de Março de 1871, apresentou um projeto autorisando o govêrno a garantir juro de $7 \%$ sobre o capital não excedente de vinte mil contos de réis a companhia ou companhias que, dentro ou fóra do Império, por encomenda de fazendeiros e à custa dêsté, introduzirem imigrantes. Este projeto foi muito criticado como oneroso aos fazendeiros; mas, que o digam eles, agora, atualmente, si não lhes tem sido muito mais caro obter colonos pelo atual sistema de proteção a introdutores!

Em relação a despesas produtivas, afirmou que devem tomar o primeiro lugar as que referem-se à instrução e educação da mucidade e ao esplendor do culto religioso, porque, dizia ele, "sabe-se quanto a moralisação do povo impõe sem esforço o amor ao trabalho, a bôa fé nas transações e a seguridade geral".

Em relação aos serviços públicos por meio de companhias anônimas, entendia que as companhias estrangeiras têm a inapreciavel vantagem de deixar que os capitais nacionais fundem outras indústrias além de poderem. ser melhor subordinadas à ação fiscalisadora do govêrno e oferecer ao público garantias de comodidade, que os interesses dos acionistas longínquos mais dificilmente conseguirão destruir: "Compreenda-se, dizia ele, a conveniencia de não procurar empregar capitais da Provincia em empresas de tão grande valor, mal aplicando o principio de iniciativa particular a associações aqui organisadas". Mas, onde se ostentou o seu maximo esforço foi na guerra terrivel que moveu ao projeto que pretendeu estabelecer a obrigatoriedade do ensino primário: “As assembléias provinciais, dizia ele, não podem estatuir o principio como preceito legislativo, 
porque a obrigação de educar e de fazer instruir os filhos, fazendo parte dos deveres paternos, só póde ser regulada pelo direito cívil, que não é da competencia de tais assembléias... Já temos sábia legislação civil sobre o assunto e apenas, pois, sente a falta de execução de tais leis por parte dos juizes competentes. Basta-nos, apezar de tudo, a fiscalisação dos magistrados, porque um país livre não póde nem deve tolerar, relativamente ao pátrio poder, a odiosa intervenção de agentes do poder administrativo".

Multipliquem-se as escolas, facilite-se ao pai a educação do filho; mas, não penetre no lar doméstico quem não está revestido da iurisdição de conhecer os atos do pátrio poder.

A verdade é que como todas as reformas feitas por emulaçãe, - ensino primário obrigatório teve a sorte de todas as medidas inuteis e inexequiveis. 